\title{
The origin of proteinuria at high altitude
}

\author{
M.H. Winterborn, A.R. Bradwell, I.M. Chesner and G.T. Jones \\ Department of Paediatrics, East Birmingham Hospital, Bordesley Green East, Birmingham B9 5ST, UK.
}

\begin{abstract}
Summary: Urinary protein excretion was measured before and after the intravenous infusion of lysine in 14 normal subjects after 4-6 days' acclimatization at $4846 \mathrm{~m}$. Urinary albumin excretion before lysine was elevated in 11 subjects but alpha ${ }_{1}$-microglobulin was detected in only four. After lysine a large increase in albumin excretion occurred in all subjects. Together with the absence of alpha $a_{1}$-microglobulin before lysine this implies that increased glomerular capillary permeability is the major cause of proteinuria after acclimatization to high altitude. The estimated minimum glomerular fluid albumin concentration was increased two to three fold above the published values in normal controls.
\end{abstract}

\section{Introduction}

Increased albumin in the urine on ascent to high altitude has previously been demonstrated. ${ }^{\prime} \mathrm{We}$ showed a significant correlation between the height attained and both the concentration and the excretion rate of urinary albumin in normal subjects after rapid ascent. ${ }^{2}$ The increase in albumin excretion rate was virtually abolished in subjects treated with acetazolamide. Variations in the albumin excretion rate were related closely to the degree of hypoxia. It is unknown whether this effect of hypoxia is mediated by increased glomerular capillary permeability or decreased tubular protein reabsorption.

It has been shown that intravenous lysine acts as a powerful but transient inhibitor of renal tubular protein reabsorption ${ }^{3}$ offering a means of distinguishing between tubular and glomerular proteinuria in normal man. The purpose of the present study was to determine the site of the renal protein leak and the effect of acetazolamide in normal subjects who had ascended recently to high altitude.

\section{Methods}

Fourteen men aged $23-45$ years were studied after 4 6 days at $4846 \mathrm{~m}$ having walked to that altitude. ${ }^{4}$ Eight subjects were taking acetazolamide $500 \mathrm{mg}$ once daily (Group A) and six a placebo (Group P) on a double blind basis. Following a fast of at least 4 hours subjects took $250 \mathrm{ml}$ of clear fluid by mouth every $20 \mathrm{~min}$ during the test. After emptying the bladder a baseline 20-minute urine collection was made. L-lysine hydrochloride $30 \mathrm{~g}$ in $100 \mathrm{ml}$ (chloride $180 \mathrm{mmol} / \mathrm{l}$ ) was then infused over $10 \mathrm{~min}$ using $50 \mathrm{ml}$ syringes and double

Correspondence: M.H. Winterborn M.B., B.S., F.R.C.P.
$0.45 \mu \mathrm{m}$ filters. A second timed urine collection was made during and for 20 minutes after the lysine infusion. A 21-gauge 'butterfly' needle in a forearm vein was used for the lysine infusion and for blood samples at the mid-points of the urine collection periods. Clotted blood was centrifuged and the serum separated. Urine volumes were measured and $3 \mathrm{ml}$ aliquots taken. The serum and urine samples were preserved with sodium azide and transported back to Birmingham for analysis. Creatinine in blood and urine was determined by a centrifugal analyser. Albumin and alpha ${ }_{1}$-microglobulin were determined in urine by radial immunodiffusion. The increase in albumin excretion was expressed as a percentage of the rate after lysine (i.e. the rate approaching maximum filtration of albumin) rather than as a percentage of the baseline albumin rate. This allowed the protein subjected to tubular reabsorption to be expressed as a fraction of the total filtered. The statistical significance of differences between the groups was established by the Mann-Whitney rank-sum test. Results are expressed as mean \pm standard deviation.

\section{Results}

\section{Before lysine}

Urine flow rate was $3.5 \pm 3 \mathrm{ml} / \mathrm{min}$ in Group A and $0.52 \pm 0.3 \mathrm{ml} / \mathrm{min}$ in Group $\mathrm{P}(P<0.001)$. Creatinine clearance was $111.5 \pm 64.3 \mathrm{ml} / \mathrm{min}$ in Group $A$ and $49.5 \pm 39.4 \mathrm{ml} / \mathrm{min}$ in Group $P(P<0.05)$. Albumin excretion rate was $59 \pm 39 \mu \mathrm{g} / \mathrm{min}$ in Group $A$ and $115 \pm 198 \mu \mathrm{g} / \mathrm{min}$ in Group P (not significant). It exceeded the upper limit of normal $(15 \mu \mathrm{g} / \mathrm{min})$ in all of Group A but in only 3 of Group P (Figure 1). Alpha,-

(C) The Fellowship of Postgraduate Medicine, 1987 


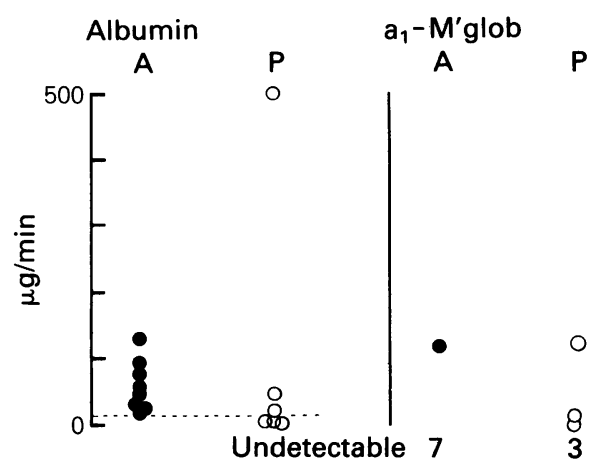

Figure 1 At high altitude basal albumin excretion was increased to $15-140 \mu \mathrm{g} / \mathrm{min}$ in most subjects. The upper limit of normal albumin excretion is $15 \mu \mathrm{g} / \mathrm{min}(---)$. Alpha $a_{1}$-microglobulin was only detectable in four subjects. There was no difference between those taking acetazolamide (A) and placebo (P).

microglobulin was detectable in the urine of only one subject in Group A and 3 in Group P.

The arterialized capillary $\mathrm{Pa}, \mathrm{O}_{2}$ measured within 24 hours of the lysine study was $5.83 \pm 0.35 \mathrm{kPa}$ in Group $A$ and $5.41 \pm 0.35 \mathrm{kPa}$ in Group $\mathrm{P}(P<0.02)$. There was no significant correlation between albumin excretion rate and $\mathrm{Pa}, \mathrm{O}_{2}(r=0.35)$.

\section{After lysine}

Urine flow rate increased to $6.8 \pm 4.2 \mathrm{ml} / \mathrm{min}$ in Group $A$ and to $5.1 \pm 5.9 \mathrm{ml} / \mathrm{min}$ in Group $P$ but this was not accompanied by any significant change in creatinine clearance which was $111.8 \pm 31.1 \mathrm{ml} / \mathrm{min}$ in Group $A$ and $148.7 \pm 171 \mathrm{ml} / \mathrm{min}$ in Group $P$. Albumin excretion rate increased (Figure 2) to $480 \pm 250 \mu \mathrm{g} / \mathrm{min}$ in Group A and to $754 \pm 954 \mu \mathrm{g} /$ min in Group P with no significant difference between the groups. The amount by which albumin excretion increased, expressed as a fraction of the rate after lysine infusion, was $78 \pm 19 \%$ in Group $A$ and $74 \pm 29 \%$ in Group P. The increase in albumin excretion was less than $60 \%$ in two members of each group. Only one had detectable alpha ${ }_{1}$-microglobulin in his urine prior to lysine infusion. The increase in albumin excretion was accompanied by the appearance of alpha ${ }_{1}$-microglobulin in the urine of every subject: in Group $A$ the alpha $a_{1}$-microglobulin excretion rate was $598 \pm 325 \mu \mathrm{g} / \mathrm{min}$ and in Group $P$ was $661 \pm 571 \mu \mathrm{g} / \mathrm{min}$.

An estimate of the minimum albumin concentration in glomerular fluid (GFA) was made in each subject using the measurements of creatinine clearance and albumin excretion in the urine after lysine infusion. In Group A the GFA was $5.0 \pm 2.1 \mathrm{mg} / 1$ and in Group P

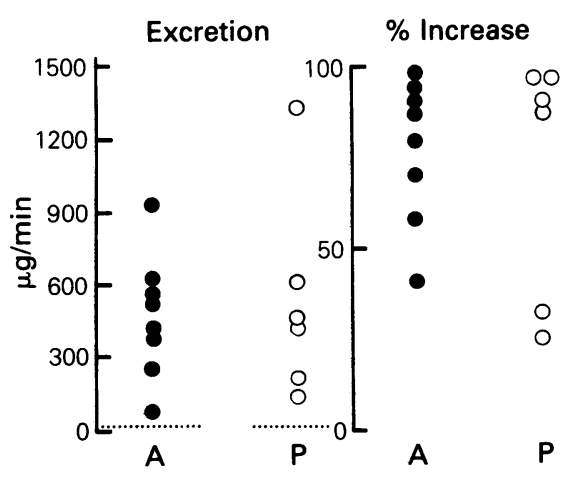

Figure 2 Albumin excretion rate after lysine was greatly increased (-- indicates $15 \mu \mathrm{g} / \mathrm{min})$. The increase, expressed as a fraction of the post-lysine excretion rate, exceeded $60 \%$ in all but 4 subjects. Acetazolamide (A); placebo (P).

it was $4.9 \pm 1.8 \mathrm{mg} / \mathrm{l}$ (not significant) (Figure 3). In a repeat lysine infusion in one subject in UK the value was $3.4 \mathrm{mg} / 1$.

Twenty-four hours after the study 12 of the 14 subjects noticed pain in the forearm vein which hag been used for the infusion of lysine and the vein was found to be thrombosed, presumably due to locea irritation by the hypertonic solution.

\section{Discussion}

Proteinuria is a constant finding in man after rapid ascent to altitudes in excess of $3,000 \mathrm{~m}$. Previous

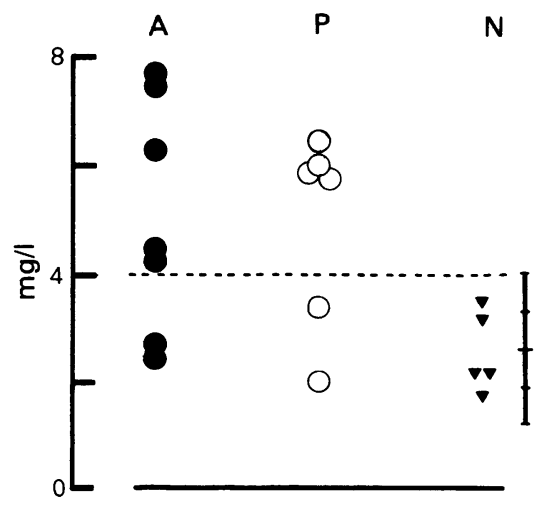

Figure 3 The estimated minimum glomerular fluid albumin concentration was above the normal range in 9 out of 13 subjects with no difference between those taking acetazolamide (A) and placebo (P). $\mathbf{N}=$ normal values, $2.6 \pm 0.7 \mathrm{mg} / 1$ (taken from Mogensen \& Sølling. ${ }^{3}$ ) 
studies have shown a correlation between the quantity of proteinuria and both the degree of hypoxia ${ }^{2}$ and the height attained.' Furthermore, it was shown that treatment with acetazolamide diminished high altitude proteinuria presumably by reducing hypoxia. However, the results of the present study, which was conducted after a slow ascent from $1500 \mathrm{~m}$ and acclimatization for four days at $4846 \mathrm{~m}$ showed no significant effect of acetazolamide on the proteinuria. Nor was there any significant correlation between the proteinuria and $\mathrm{Pa}, \mathrm{O}_{2}$, perhaps because the range of oxygen tensions was small.

Two hypotheses have been advanced for the cause of high altitude proteinuria. Firstly, the active tubular reabsorption of protein might be inhibited by hypoxia. This suggestion would be supported by the appearance in the urine of low molecular weight proteins such as alpha ${ }_{1}$-microglobulin which are normally reabsorbed completely in the proximal tubule. However, the present study revealed alpha ${ }_{1}$-microglobulin in the urines of only a few subjects while nearly all showed increased albuminuria. Secondly, an increase in capillary permeability secondary to hypoxia might lead to a greater filtered load of protein exceeding the reabsorptive capacity of the renal tubule.

In the present study we used intravenous L-lysine hydrochloride which is a strongly positively charged essential amino acid with a normal serum concentration of $0.15-0.26 \mathrm{mmol} / \mathrm{l}$. The intravenous infusion of $30 \mathrm{~g}$ lysine would have increased the serum concentration to approximately $20 \mathrm{mmol} / 1$. An important effect of intravenous lysine is the competitive inhibition of proximal protein reabsorption first described by Mogensen \& Solling, ${ }^{3}$ whose protocol we followed. The inhibition is not complete so the estimate of albumin concentration in the glomerular filtrate following lysine infusion must be regarded as a minimum value.

\section{References}

1. Rennie, I.D.B. \& Joseph, B.J. Urinary protein excretion in climbers at high altitude. Lancet 1970, i: 1247-1251.

2. Bradwell, A.R. \& Delamere, J.P. The effect of acetazolamide on the proteinuria of altitude. Aviat Space Environ Med 1982, 53: 40-43.

3. Mogensen, C.E. \& Sølling, K. Studies on renal tubular protein reabsorption: partial and near complete inhibition by certain amino acids. Scand J Clin Lab Invest 1977 , 37: 477-486.

4. Bradwell, A.R. \& Coote, J.H. The BMRES 1984 Medical Research Expedition to the Himalayas. Postgrad Med J 1987, 63, 165-167.
Upright posture increases urinary albumin excretion from 2.6 to $5.9 \mu \mathrm{g} / \mathrm{min}$. ${ }^{6}$ Similarly, albumin excretion will rise from 4 to $7 \mu \mathrm{g} / \mathrm{min}$ with oral water loading. ${ }^{7}$ However, though our subjects remained upright and were water-loaded, the changes we observed were much greater than would be accounted for by these factors.

The rates of urine flow after lysine were the same in subjects taking placebo or acetazolamide. However, the initial rates of urine flow were markedly different being much lower in the placebo group. It is unlikely that chronic acetazolamide treatment in normal subjects was having any basal diuretic effect. It is possible that acetazolamide causes a more rapid response to water loading.

The basal and post-lysine albumin excretion rates which we report are of the same order as those reported by Mogensen et al. ${ }^{5}$ in a group of diabetic patients with normal serum creatinine but elevated basal albumin excretion rates: $46.6 \pm 18 \mu \mathrm{g} / \mathrm{min}$ rising to $366.8 \pm 108 \mu \mathrm{g} / \mathrm{min}$ after lysine. The increased glomerular permeability to protein in diabetic patients can be related to morphological changes in the capillary basement membranes of the glomerulus. In contrast the rapid changes in permeability related to altitude make it unlikely that hypoxia is causing a similar lesion. It is unknown whether the alteration in glomerular permeability with hypoxia is mediated by a direct effect on the glomerular epithelial cells or secondarily by local hormonal effects on renal blood flow. If the factor which causes the increased permeability can be identified it raises the possibility of using an antagonist to treat or reduce the severity of acute mountain sickness.

Our results show that increased glomerular capillary permeability occurs in healthy men at high altitude and that it is the most important cause of proteinuria in the majority.

5. Mogensen, S.E., Vittinghus, E. \& Sølling, K. Abnormal albumin excretion after two provocative renal tests in diabetes: physical exercise and lysine injection. Kidney Int 1979, 16: 385-393.

6. Montagna, G., Buzio, C., Calderini, C., Quaretti, P., \& Migone, L. Relationship of proteinuria and albuminuria to posture and to urine collection period. Nephron 1983, 35: $143-144$.

7. Viberti, G.C., Mogensen, C.E., Keen, H., Jacobsen, F.K., Jarrett, R.J. \& Christensen, C.K. Urinary excretion of albumin in normal man: the effect of water loading. Scand J Clin Lab Invest 1982, 42: 147-157. 